\title{
Prevalence of Teachers' Professional Malpractices in Tanzanian Public Secondary Schools: What Ought to Be Done?
}

\author{
Hamisi Mfaume ${ }^{1}$, Margareth Bilinga ${ }^{1}$ \\ ${ }^{1}$ Dar es Salaam University College of Education Faculty of Education, Tanzania \\ Correspondence: Hamisi Mfaume, Dar es Salaam University College of Education Faculty of Education, Tanzania.
}

Received: May 13, 2016

doi:10.11114/jets.v5i2.2106
Accepted: October 28, 2016 Online Published: December 26, 2016

URL: http://dx.doi.org/10.11114/jets.v5i2.2106

\begin{abstract}
This study explored stakeholders' views on preventive measures towards increasing teachers' malpractices in schools in Tanzania. Specifically, the study sought to identify prevalent forms of teachers' malpractices; explore factors for their occurrence; and explore views on how to forestall the problem. It draws on qualitative and quantitative data generated from 75 respondents including the Teachers' Service Department (TSD) officers, education officers, school inspectors, teachers, and students. The data were generated from questionnaires, interviews, Focused Group Discussion, documentary search and non-participant observation. Data analysis involved both qualitative and quantitative approaches. While Qualitative data were subjected to thematic analysis, Quantitative data were converted into frequencies and percentages and then presented in tabular forms. The findings unveiled that absenteeism, abusive and violent behaviours, sexual abuse to mention a few were prevalent forms of teachers' malpractices in schools. Their occurrence were attributed to teachers' low salaries and remunerations, poor living and working conditions, influence of science and technology, lack of professional knowledge and poor management as well as infrequent visits and inspections of schools. In order to remedy the problem respondents proposed that teachers' needs and plights to be addressed timely, funds allocated to the TSD should be raised and involvement of stakeholders in all decision making related to the teaching profession. It was also suggested for the TSD to be empowered to oversee teachers' discipline both in public and private owned schools. In the light of the findings, the study concludes that teachers' malpractice is still a problem of great concern in rural and urban schools in Tanzania. Therefore, rigorous collaborative effort by the government and the wider community is needed in order to promote desirable professional behaviour in schools.
\end{abstract}

Keywords: professional malpractice, compliance, teachers' codes of conducts

\section{Introduction}

Over the years, provision of quality education has been one of the Tanzania's ultimate goals (United Republic of Tanzania, (URT), 1995). Quality education is seen as a catalyst for creation of a well-educated nation towards the year 2025 (Ministry of Education Culture, 2000). Realization of this goal however, is dependent upon the quality of serving teachers. Teachers' quality does not simply refer to academic qualifications and training status alone. Rather, it encompasses the commitment and ethical behaviour as well (van Nuland, 2009). The fact that teachers are entrusted with most valuable resources, children, they are expected to promote and maintain a highest standard of conduct in all situations for better execution of their duties (Pehlivan, 1998; VanNuland and Khandelwal, 2006). Their conducts either within or outside school compounds has had greatest and life-long impacts in the moral upbringing of the children, the profession, and the nation as a whole (Agih, 2013).

To ensure that teachers observe core ethical values, various countries have developed professional codes of conduct in the education sector (Van Nuland \& Khandelwal, 2006). In Tanzania, the code is developed by the Public Service Commission (PSC), an autonomous body under the President's office (United Republic of Tanzania, 2002; 2003). The code of conduct requires teachers to be responsible to children under their care, the community in which they live, the profession, the employer and the state. As per the public service Act No. 8 of 2002, enforcement of the code is entrusted to the Teachers' Service Department (TSD) which is one of the five departments in the PSC (Public Service Commission, 2010). The department has been taking various initiatives to enforce the code and ensure that all teachers comply with it. The initiatives have included provision of seminars and workshops, guidance and counselling, reprimands and dismissal of perpetrators (Mfaume, 2012). For instance, in 2008 about 300 misbehaving teachers were dismissed country wide (TSD, 2008). 
With all these measures teachers were expected to behave exemplary. On contrary reports from a growing body of researches (Boimanda, 2004; Anangisye and Barret, 2006; Anangisye, 2006; 2010; 2011; Oziambo 2010; Fussy, 2012; Mfaume, 2012) and mass media (Edmund, 2011; Mussa, 2011) but to mention a few, indicate that incidents of teachers' malpractices are increasingly becoming prevalent. If not addressed, this situation threatens to undermine the well intentioned government efforts to create a well dedicated teaching force and improve the quality of education in the country (Anangisye and Barret, 2006). Whereas the problem becomes critical, there is paucity of empirical studies focused on establishing intervention to remedy the persisting problem. Most of the related studies that have been conducted in the country (Anangisye 2010; 2011; Boimanda, 2004; Oziambo, 2010; 2013; Fussy, 2012; Mfaume, 2012; Jerome, 2013) have had primarily hinged on investigating the nature, causes, effects and challenges towards curbing teacher malpractices. Hence, the reason for undertaking the current study.

\subsection{Purpose of the Study}

The purpose of this study was to find out effective initiatives to prevent teachers' malpractices in schools in Tanzania. More specifically the study sought to:

i. Identify prevalent forms of teacher malpractices in schools.

ii. Establish the factors for prevalence of teacher malpractices in schools.

iii. Explore views from education stakeholders' on ways to address the problem

\section{Methodology}

The study employed mixed research approach whereas both quantitative and qualitative approaches were concurrently employed. Based on the nature of the study objectives, the method was considered appropriate as it allowed researchers to triangulate the findings of the study from the separate qualitative and quantitative data (Jonhson and Turner, 2003). Also the approach helped the researchers to exploit the strengths and offset the weaknesses inherent in each approach (Cresswell, 2009). While the qualitative approaches helped the researchers to generate in-depth opinions of respondents on the subject, the quantitative approach helped in maximizing objectivity of the study. Thus, mixed method made it easier for the researchers to generate reliable data, cross-validate the data and corroborate the data and the findings of study (Creswell 2009).

\subsection{Sample and Sampling Techniques}

A total of 75 respondents selected from four rural and urban schools participated in the study. Specifically the sample included 32 teachers, 32 students, 1 regional and 3 TSD Secretaries, 2 District Education Officers (DEOs), 2 Chief School Inspectors, and 4 Heads of Schools. Size and selection of samples considered among other factors, the size of the population, purpose of the study, information required and time (Best and Khan, 2006). The study deployed a stratified random sampling and purposive sampling techniques to obtain respondents for the study. Stratified random sampling was used in selecting two rural and two urban schools. Accordingly, the technique was used to select students and teachers based on gender for questionnaires and focus group discussion. On the other hand, purposive sampling based the virtue of respondents' positions was used to select regional and districts' TSD secretaries, Districts' Education Officers (DEOs), Chief District School Inspectors and Heads of Schools for interviews.

\subsection{Data Collection Methods}

Five types of data collection instruments were used in this study: documentary search, questionnaires, interviews, Focus Group Discussions and observation checklist.

\subsubsection{Documentary Search}

Documentary search was used to obtain information related to teachers' disciplinary and attendances records from TSD and school heads' offices. The information collected through this technique enabled the researcher to cross- check the reliability and validity of the information collected through the questionnaires and interviews.

\subsubsection{Interview}

Semi-structured interviews were held in order to obtain detailed information on the subject from regional and district TSD secretaries, DEOs, District Chief School Inspectors and heads of schools. Interview provided the researchers with the opportunity to establish rapport with respondents and restructure the questions whenever it was deemed necessary in order to elicit detailed information on the subject (Tellis, 1997, Kothari, 2004; Cohen et al., 2007). Each interview session lasted for about 45 to 60 minutes.

\subsubsection{Questionnaires}

Open and close-ended questionnaires were employed to collect data from teachers and students. Open-ended questions allowed the respondents to explain their views on particular issues while close-ended questions permitted the 
respondents to choose among the given responses only (Best and Khan, 2006). Questionnaires were used to generate data related to forms of teachers' malpractices experienced in schools as well as perceived factors for their occurrences. Questionnaires were distributed to students in classes and teachers in staff-rooms. Then questionnaires for students were instantly collected after they were filled while those for teacher were collected within two days since teacher respondents requested for ample time to fill in the questionnaires.

\subsubsection{Focus Group Discussions}

Focused group discussions were held with teachers and students who filled questionnaires so as to get their experience with, and reactions on subject under scrutiny (Patton, 2002; Cohen et al., 2000), and more importantly to check for authenticity of their responses provided through questionnaires. Each discussion session involved a minimum of five respondents and took between 45 to 60 minutes.

\subsubsection{Observation}

Non-participant observation was employed in generating data related to teachers' actions particularly, attendance, punctuality, and teacher-student and teacher-teacher relationships. Researcher (Yin, 2011) maintained that observation increases the chance for the researcher to obtain a valid and realistic picture of the phenomenon being studied. Thus, observation provided the researcher with an opportunity to get empirical evidence of what was actually taking place in the real situation.

\subsection{Data Analysis}

Data analysis is a process that implies editing, coding, classification and tabulation of collected data (Kothari, 2004). As the study involved qualitative and quantitative data, the analysis process was also governed by the two approaches. Qualitative data were subjected to thematic analysis (Creswell, 2009). The analysis involved six concurrent stages. The researchers got familiarized with the data, generated initial codes, searched for themes, reviewed themes, defined and named themes and finally produced the report (Braun and Clarke, 2006). Quantitative data concerning the forms and causes of teachers' malpractices were categorized and converted into frequencies and percentage then presented in tabular forms.

\section{Results}

\subsection{Prevalent Forms of Teachers' Malpractices in Secondary Schools}

The first research objective explored common types of teachers' malpractices in the secondary schools. The quantitative findings are summarized in Table 1 followed by qualitative descriptions.

Table 1. Teachers and students' responses on prevalent forms of teachers' malpractices in schools

\begin{tabular}{|c|c|c|c|c|}
\hline \multirow[t]{4}{*}{ Type of teacher malpractice } & \multicolumn{4}{|c|}{ SCHOOL LOCATION } \\
\hline & \multicolumn{2}{|c|}{ Mbeya urban } & \multicolumn{2}{|l|}{ Mbeya rural } \\
\hline & Teachers & Students & Teachers & Students \\
\hline & $\mathrm{N}=16$ & $\mathrm{~N}=16$ & $N=16$ & $\mathrm{~N}=16$ \\
\hline Absenteeism & $14(87 \%)$ & $16(100 \%)$ & $13(81 \%)$ & $14(87 \%)$ \\
\hline Abusive and violent behaviours & $13(81 \%)$ & $11(69 \%)$ & $12(75 \%)$ & $12(75 \%)$ \\
\hline Love affairs & $04(25 \%)$ & $10(62 \%)$ & $08(50 \%)$ & $09(56 \%)$ \\
\hline Private tuition & $12(75 \%)$ & $12(75 \%)$ & $04(25 \%)$ & $05(31 \%)$ \\
\hline Improper dressing & $03(18 \%)$ & $07(43 \%)$ & $03(18 \%)$ & $04(25 \%)$ \\
\hline Cheating/forgery & $10(62 \%)$ & $07(43 \%)$ & $01(06 \%)$ & $01(06 \%)$ \\
\hline Theft & $03(18 \%)$ & $07(43 \%)$ & $01(6 \%)$ & $06(37 \%)$ \\
\hline Corruption & $05(31 \%)$ & $10(62 \%)$ & $01(06 \%)$ & $02(12 \%)$ \\
\hline Examination fraud & $0(0 \%)$ & $03(03 \%)$ & $02(12 \%)$ & $0(0 \%)$ \\
\hline
\end{tabular}

Looking at the data presented in the table, It is clear that there were a range of teacher malpractices both rural and urban schools within Mbeya region. However, the problem was more critical in urban schools than its counterpart. Their occurrence was of great concern to the TSD as the interviewee regional secretary admitted:

...teachers' discipline is declining not only in my region but all over the country. In the past it was uncommon to find a teacher implicated in a certain kind of malpractice as it is recently the case...

Teacher absenteeism was the most critical form of teacher malpractices in schools. More than $80 \%$ of teacher and student respondents had experienced the problem in their respective schools. Similarly, all interviewees confessed that a majority of teachers were often absent in schools without official permission.

...teachers in our region are implicated in a number of malpractices, amongst all absenteeism is the leading one...many teachers are dismissed annually as a result of this... 
Abusive and violent behaviours were ranked second after teacher absenteeism. More than $3 / 4$ of teacher and student respondents affirmed that such practices were common in their respective schools. The practices were also observed by researchers in one of the urban schools. They heard a female teacher shouting at her students: "Nyie karume kenge msinihangaishe mimi sio bibi yenu!" [You crocodile don't disturb me. I am not your grandmother"!-Researchers' translation]". Likewise, though the government ordered corporal punishments to be used as a last resort after the approval of school heads, all interviewees acknowledged that the punishments were frequently and informally used. Students in all schools complained of psychological and physical harm they experienced from such kind of punishments. Affirming this during FGD one student in rural school put it thus:

Corporal punishment in our school is used as a first, not a last resort... we are often punished without being given a chance to argue...we are physically and psychologically hurt but no nobody cares...

The claims were approved by researcher's presence in one of the schools. He observed a male teacher caning his students on the ground that they failed to collect their annual examination reports. While canning the teacher shouted angrily, "why did not you bring envelopes? Do you want me to bring you the reports at your homes...how much will you pay for me?" The quotes concurs the one by Jerome (2014). He quoted students claiming:

We are often insulted by female teachers than male teachers...in my view nothing else than jealous and lack of confidence that make teachers feel they are despised all the time...

In our school females teachers are experts in abusive language. They insult us as if we share husbands [laughers]....seriously we are psychologically tortured...

Students' sexual abuse was a third form of malpractice in schools. This was indicated by $25 \%$ of teachers in urban and $50 \%$ in rural schools as well as $62 \%$ of students in urban and $56 \%$ of students in rural schools. Consequently, all the interviewees acknowledged that some teachers, males in particular, engaged in sexual affairs with their own students in secret ways. Their assertions were proved by the reviewed TSD's records. The records indicated that between the years 2001 to 2007 about eleven teachers in the region were dismissed on the offence.

Moreover, despite a specific order by the government to ban private tuition by serving teachers, the findings indicated that private tuition was still practiced by teachers, more in urban than in rural areas. Mainstream teachers were reported to associate themselves with mushrooming private coaching centres out of school compounds. As a result they gave less attention in classroom teaching in order to motivate students to attend their tuition classes. Consider the following remark from a student:

...Sir! Some of our teachers are always chatting in the staff room instead of attending to their class periods... in turn they fail to cover the topics hence they force us to attend private tuitions.

Improper dressing among teachers was noticeable both in rural and urban schools. This was indicated by $18 \%$ of teachers both in urban and rural with $43 \%$ of students in urban as well as $25 \%$ in rural. It was also affirmed during the interviews held with heads of schools and researchers' own observation. The nature of this problem however, varied among teachers in rural and urban schools. In urban school mostly the problem involved female teachers who appeared at schools with flip-flops shoes, short or tight clothes made out of transparent materials while in rural counterpart teachers appeared dirty with crumpled clothes as well as locally made sandals. For instance, in his presence at urban school ' 1 ' researchers evidenced an incident where by a female teacher was in shabby shoes which created some chaotic kind of noises to the extent of disturbing classroom sessions. Improperly dressed teachers are more often than not portraying infidelity towards their students, professional norms as well as principles and subsequently, loss of respect is accorded to the entire profession.

Forgery and/or cheating were found to be among the prevalent forms of malpractices mostly in urban than in rural counterpart. It was indicated by $62 \%$ of teachers and $43 \%$ of students in urban schools against only $06 \%$ of teachers and students in rural schools. Associated with forgery were the use of forged academic certificates and/or using other peoples' academic certificates as a way of getting employment, embezzlement of school funds through forged receipts as well as teachers' tendency to present forged health documents so as to get favour in various matters like transfer or leaves. However, records from the TSD indicated that for the period between the years 2004 to 2007 ten teachers were dismissed from service as a result of forgery and/or cheating.

Theft was also evident among teachers in urban schools. Teachers were accused of stealing teaching and learning materials, building materials, buckets as well as school funds. They were also involved in stealing academic certificates of students who had completed schools and selling them to other people. Correspondingly, reviewed TSD records indicated that between the year 2004 and 2005 four teachers were dismissed after being found guilty of stealing books, academic certificates, other teachers' salaries as well as students' payments. 


\subsection{Factors for Prevalence of Teachers' Malpractices}

Respondents were required to indicate the perceived factors for prevalence of teachers' malpractices. Knowing such factors was important to provide appropriate solution to the problem. Thus, findings are presented in Table 2

Table 2.Teachers responses on perceived sources of Teacher malpractices in schools

\begin{tabular}{|c|c|c|c|c|}
\hline \multirow[t]{2}{*}{ sources of teachers' malpractices } & \multicolumn{2}{|c|}{ Urban $(N=16)$} & \multicolumn{2}{|c|}{ Rural (N=16) } \\
\hline & $\mathbf{N}$ & $\%$ & $\mathbf{N}$ & $\%$ \\
\hline Low salaries and remunerations & 12 & 75 & 11 & 69 \\
\hline Poor living and working conditions & 10 & 62 & 15 & 94 \\
\hline The influence of science and technology & 10 & 62 & 04 & 25 \\
\hline Lack of professional knowledge & 07 & 43 & 12 & 75 \\
\hline Poor management of teachers & 11 & 69 & 07 & 43 \\
\hline Infrequent visit by the TSD officials & 11 & 69 & 13 & 81 \\
\hline Nature and character of the entrants in teaching & 5 & 31 & 4 & 25 \\
\hline
\end{tabular}

From the data indicated in the table, reasons behind teacher malpractices were summarized and classified as economic, social, managerial, professional as well as technological related.

\subsection{Economic Factors}

Respondent teachers $75 \%$ in urban and $69 \%$ in rural schools attributed prevalence of teachers' malpractices to low salaries and remunerations. They claimed that salaries they were paid were scanty for them to meet necessities including house rent, water and electricity bills, transport and meals but to mention a few. In order to sustain they had to complement the salaries by engaging in informal income generating activities-petty business, farming and private tuitions. These activities were more often conducted during class hours. Acknowledging this, the headmaster in one of the rural school had this to say:

...Aah! Our salary is too meagre when it is compared to the real life situation. This than all, exacerbates teachers absenteeism as they attend such private projects which supplement their meagre salaries.

\subsection{Social Factors}

Most of the teachers $62 \%$ in urban and $94 \%$ in rural schools cited poor living and working conditions among the key factors for prevalence of teacher malpractices. Associated with this, were heavy workloads, large class sizes, and limited career development opportunities. They also mentioned absence of ablution blocks, furniture and favourable housing in most of schools particularly in rural. These problems frustrated teachers to the extent that indulged into excessive alcoholism, lateness and/or absenteeism.

\subsection{Technological Related Factors}

The development of science and technology was among the perceived factors for prevalence of the problem. It was reported that technological devices - television, mobile phones and internets but to mention a few, exposed teachers to a myriad of immoral and unethical conducts. Inadvertently, some of teachers mostly the young adopted and/or imitate and practiced the same without consideration of cultural differences and their professional principles.

\subsection{Professional Knowledge Related Factors}

Limited professional knowledge among teacher was found one of the reasons behind marvellous teacher malpractices in schools. $43 \%$ of teachers in urban and $25 \%$ in rural and all the interviewees acknowledged that many teachers were less familiar of professional code of ethics. They indicated absence of core courses related to teacher professionalism in most of the universities and teacher colleges and lack of in-service trainings on teacher ethics to have made teachers blindly implicated in malpractice.

\subsection{Managerial Factors}

All interviewees and $69 \%$ of teachers in urban and $43 \%$ in rural attributed the prevalence of teacher malpractices to inattentive educational managements. It was claimed that teachers indulged in malpractices simply because they are neglected by managements at all levels. The management is insensible of attending their chronic claims - promotions, transfers, allowances, and salary arrears'. They also claimed of distortions in the recruitment, deployment and favouritism in career development opportunities among education managers at all level.

Infrequent visit of schools by the TSD and education officials were reported to have exacerbated the problem. Teachers $69 \%$ in urban and $81 \%$ in rural schools admitted that their schools were hardly visited and inspected. As a result a number of malpractices were committed with impunity. In regard to that a rural school ' 2 ' head master lamented:

...for your information, the TSD officials are office based. They never visit teachers and educate them on profession related issues...For instance; none of the TSD Officers has visited this school and those I worked before. I am sure that 
leaving out those schools allocated nearby their offices they are not aware of where other schools are. Wonderfully, [a smile] the rural district TSD office is at the centre of Mbeya municipality [laughter]...

In addition, the urban TSD secretary acknowledged that:

“...As I have said earlier, we know that regular visiting of schools is very important but we fail to do so because of financial constraints and shortage of man power"

The preceding quotes indicate that schools are infrequently visited or not visited at all such that teachers' indulged in unbecoming behaviours with impunity.

The other identified problem was the nature of students admitted into teaching profession. In the study more than $70 \%$ of the respondents reported that an entry criterion to the field was a problem. Majority of teachers enter the profession unwillingly after realising that their goals were not met in their first selections. Even worse, in applicants with poor grades are admitted into teacher education programmes while best performers are enrolled in fields like engineering, law and medicine. According to teachers this issue can lead to professional problem because teachers are teaching unwillingly.

\subsection{Stakeholders Views on Ways to Remedy the Problem}

Respondents were asked to propose ways to forestall the problem. Data regarding this objective were mainly obtained through interviews held with TSD officials, education officers, school inspectors as well as heads of schools and focused group discussions conducted with teachers and students. The views and opinions given were analysed and are presented hereunder:

Fulfilment of teachers' needs: all respondents regardless of their location were of the view that teachers' employers should provide teachers with all their prerequisites - teaching and hardship allowances, adequate salaries, salary arrears and opportunities for professional development once they meet the laid down criteria. Stressing on this the rural chief school inspector commented:

Unless teachers' claims such as salary arrears, increments, and subsistence allowances are paid, teachers will never behave accordingly...

Financial support to the TSD: a majority of respondents argued for the government to provide the department with adequate fund so that the department will be able to meet its necessities such as preparing seminars and workshops on teacher ethics, visiting schools regularly, purchasing of modern facilities like computers and other stationeries as well as employing enough manpower. On this the TSD officials said:

Unlike during the time we were under the TSC, the working condition under the TSD is terrible. The department runs with a critical shortage of funds to the extent that we even fail to afford purchasing stationeries or visiting schools and educating teachers through seminars... unless we are given enough funds remedying the problem of teacher misconducts is impossible...

Brother how can you promote teacher ethics without funds...? How will you produce and disseminate teachers' code of conduct, conduct seminars and training on teacher ethics?

Codes of conduct to be reviewed and written in a simple language and they should be provided to teachers often: Most of respondents suggested for the current code of conduct to be regularly reviewed so as to accommodate important aspects central to professional accomplishment. They also argued for the code to be written in Swahili so that even other people such as parents and guardians will understand about what they address.

Stakeholder involvement in designing, developing and enforcing teachers' codes of ethics: respondents both in rural and urban areas recommended for stakeholders to be involved in each and every stage of designing and enforcing the codes of ethics. Stakeholder involvement was thought to create sense of ownership, awareness of its existence and the content of the code hence be willing to comply with because they were involved in each stage. Stressing on this during a focus group discussion with teachers in urban school ' 2 ' one teacher admitted:

...It is my twentieth year in teaching but I am not aware of who prepares codes of ethics and the processes through which they are prepared. I asked a TSD officer about this, but he simply said he was employed and found them existing... is it then possible for us to adhere to something we are not aware of?

Presence of clearly laid out procedure for lodging in complaints: It was recommended mostly by student and teacher respondents that to remedy the problem, procedures for lodging in complaints related to teachers' malpractices should be known to the wider community. It was revealed that a large number of students, parents and teachers were ignorant of the procedures through which they could send their complaints related to teacher malpractices. The procedures were known to only heads of schools as a result a number of unethical incidents including those committed by heads of 
schools remained unreported hence unknown. Therefore, once every stakeholder becomes aware of such procedures unreported incidents will appear before the respective authority hence actions will be taken against perpetrators.

We experience innumerable types of malpractices committed by teachers but we do not know where to report... [Student in rural school]

Nevertheless, respondents commented for revision of some disciplinary actions taken by TSD. They cited dismissal without a post being abolished as one to be revised because it allows a dismissed teacher to re-apply for the post after a year has elapsed, instead they argued for any dismissed teacher not to be involved in teaching for his or her life time. On this, a school inspector uttered:

Some of the TSD's actions need to be revisited. For instance, a teacher who is dismissed without his/her post to be abolished is allowed to return in the post after being out for a year...this is tantamount to annual leave ...

Finally, respondents suggested that the TSD should be mandated to oversee all teachers regardless of whether they are in private or public schools. Having the mandate to deal with all teachers, the department will have closed the opportunity which is recently used by most of the teachers to misbehave in public schools and get employed by the private owned schools.

\section{Discussion}

The findings revealed different forms of teachers' professional malpractice such as absenteeism, fraud, private tutoring and improper dressing. However, the most serious form of teachers' professional malpractice was absenteeism which was indicated by significant majority of the respondents. In their responses they revealed that absenteeism was a common problem whereby most of time classes were left unattended. Worst enough; some teachers do not report to schools for a day or two days without official permission. This finding confirms the research findings by Bennell \& Akyeampong (2007). Also, Kuleana (1999) earlier revealed that among 14 least-developed countries surveyed, Tanzania had the highest rate of teacher absenteeism. Teachers' absenteeism has serious effects on students' academic behaviour and performances. Common sense that is congruent with research findings (Finlayson, 2009) inform us that when a teacher is absent from classroom students leaning is disrupted, when he/ she is repeatedly absent, students' performance is affected negatively. Increasingly, the more the teacher is absent from school the lower the student will perform in standardized test. The fact that majority of students performed poorly in the year 2012 form four examination results could have been resulted by this factor.

The other noted form of malpractice was private tutoring which was indicated by significant majority of the respondents. It was noted that despite the efforts made by government in banning private tuitions, it was evident that the practice is still prevalent. In most schools most of the classroom teachers purposefully delayed to complete the syllabus on time so that the students could attend their private tutoring. This research finding concurs with that by Sambo (2001). He found that in urban areas in Tanzania, 70 percent of grade six pupils attended tuitions while 72 percent of teachers engaged in teaching private tuitions mostly during official hours. From the foregoing quote, it can be argued that private tuition is still a problem of great concern that denies students especially those from poor household their legal rights to quality education (Bray, 2003).

Ignoring other students' opportunity in learning is committing a serious offence since UNO declaration on human rights puts emphasis on equity and equality of education to every child. The practice is also criticised for the reason that it makes students dependent, normally with this practise students cannot stand alone even if they know what to do, they become used of letting teachers plan for them. With this practise one may think of the old proverb Give a man a fish and you feed him for a day. Teach a man to fish and you feed him for a lifetime.

Abusive and violent behaviours, students' sexual abuses and theft were also noted. Teachers stole number of item including teaching materials and certificates. This finding concurs with research findings in other countries. For example, a study carried by Bennel \& Akyeampong (2007) indicates that in Malawi a number of cases received by the Ministry of Education among others involved stealing of teaching and learning materials as well as destruction of school properties by teachers. Sexual abuse was also observed by Leach et al (2000) in Zimbabwean junior schools. He revealed that male teachers had engaged in violent and sexual intimidation of girls in a manner that became institutionalized and considered normal. Sexual abuse has far reaching consequences to both students and teachers. Sometime it may affect students to the extent that they fail to continue with their studies.

Poor management was also a cause for malpractices. Comparative, it was reported by the majority that teaching profession receives least attention. Teachers are disregarded in different aspect by their superiors and there were lots of insensible issues which affected their promotion, salary and working conditions. The finding favours Bennell \& Akyeampong (2007) assertion that the quality of management at all levels is critically important in ensuring that teachers execute their duties and behave accordingly. It also concurs with Oziambo (2010). He revealed that some head 
teachers in Rukwa region were ineffective in curbing teacher misconduct since they lacked managerial trainings and in some cases they were themselves perpetrators.

Regarding factors which culminated to such malpractices a number of factors were identified. They included economic, social, technological and managerial factors. Because of the low economic status of the country teachers were lowly paid such that they engaged in various petty businesses so as to sustain their life. This situation sometimes forces them to use school time. Such finding harmonizes the findings by UNESCO (2005) that, "in a significant number of developing countries teachers' salaries are simply not comparable with those paid in other skilled occupations of equivalent professional or even lower occupational level" Sumra (2005) also reported that because of low salary many teachers in rural Tanzania cultivated small plots of land, while in urban they kept chickens or do petty business to supplement their meagre income.

The study also reports poor Living and Working Conditions of Teachers. In Tanzania” Most of teachers' houses particularly those in rural areas are hygienically, not fit for human habitation. Also, Lumadi (2008) came across a terrible condition in rural schools in South Africa. He witnessed many schools with broken windows, cracked walls and some were grass thatched. In favour of this finding, Campbell (2003) contended "in many countries, teachers primarily carry out their professional work without being fully aware of the moral and ethical implications of their actions". This is an indicator that there is a need of equipping teachers with adequate knowledge regarding their profession so that they can behave in a respectable manner.

Nature and character of the entrants into teaching was revealed to have partly attributed to teacher violation of the code of ethics. It was reported that fire-brigade teacher recruitment style opened the door in for many unqualified candidates. The fact that most of entrants became teachers unwillingly after missing opportunities into professions of their interests, more often they indulged into a myriad of malpractices. Their practices undermined the quality of education and professional lustre entirely. In line with this observation, a research report by (Towse et al., 2002) indicated that only $10 \%$ of males and $15 \%$ of female teachers chose teaching as their first career choice and $37 \%$ opted for teaching because their grades were too low to qualify for popular professions. A study by Mkumbo (2012) acknowledged that many candidates joined the profession because of the ease with which students could become a teacher and secure a job after completion of the training.

Respondents suggested different measures to remedy the problem. Amongst others were fulfilment of teacher's needs, financial support and provision of codes of conduct. They also suggested on the reviewing and rewriting of codes of conduct in the known Kiswahili language. Teachers had the view that the codes of conduct were written in a language which is not familiar to the majority. So rewriting the codes in Kiswahili language would make it clear to everyone. This suggestion correspond to that by van Nuland \& Kandlwal (2006) that in most developing countries codes of ethics are not accessible to many teachers and are written in a difficult language in such a way that stakeholders are not in a position to approximately grasp what they address. Indeed, having codes of conduct in unclear language may cause teachers to conduct unwanted practices without their intention.

It was also suggested that for TSD to function effectively it should deal with both private and government schools. Operating only in government schools makes it ineffective because some offences are committed by teachers in private schools where the TSD is not responsible. The suggestion given by the respondents is parallel to that given by Anangisye (2006). It was revealed that currently the TSD has limited mandates to deal with teachers discipline only in public schools. As such private schools seem to be safe hidden place for dismissed teachers from public schools.

\section{Conclusions}

In the light of the findings recounted above, it has been revealed that despite the efforts that have been taken by the government and the TSD to promote discipline in the teaching profession, teacher malpractice is still a problem of great concern country wide. The problem affects the teaching and learning processes, the entire teaching profession and the wider community. Therefore, more collaborative effort must be put forth by the government and the wider community to remedy the problem in order to ensure that national and educational goals are realized.

\section{Recommendations}

For effective and successful promotion of teacher ethics and the achievement of educational goals, this study recommends for the government in collaboration with other education stakeholders to work on the views provided by stakeholders particularly improving teachers' living and working conditions, equipping the TSD with all necessary inputs in particular funds, manpower and transport facilities and entrusting it with power to deal with teachers' discipline in both public and private schools. Likewise, the Ministry for education should select qualified candidates and ensure regular visits and inspection of schools and such visits and inspection should be conducted as a regular means for training and as a method to assess violation of ethical principles and professionalism. 


\section{Acknowledgements}

Our sincere gratitude goes to all those who in one way or another devoted their efforts, time and resources that enabled us come up with this paper. Our appreciation also goes to the Journal of Education and Training studies for reviewing and accepting publication of this paper. However, any flaws encountered in this work remain our sole responsibility.

\section{References}

Agih, A. A. (2013). Extent of compliance of ethics of the teaching profession by secondary school teachers in Bayelsa state in Nigeria: Academic Journal of Interdisciplinary Studies, 2(3), 41-46. https://doi.org/10.5901/ajis.2013.v2n3p41

Anangisye, W. A. L. (2006). Educating teachers, the ethical dimension of teacher professionalism in Tanzania. Unpublished PhD Thesis, University of Edinburgh.

Anangisye, W. A. L. (2010). Promoting teacher ethics in colleges of teacher education in Tanzania: Practices and challenges. African Journal of Teacher Education, 1(1), 64-77.

Anangisye, W. A. L. (2011). Why are teachers motivated to behave unprofessionally? A qualitative-data-based-inquiry on educational stakeholders' experiences in Tanzania. A Journal of Contemporary Research, 8(1), 1-23.

Anangisye, W. A. L., \& Barret, A. M. (2005). Professional identity and misconduct: Perspective of Tanzanian teachers. Southern African Review of Education with Production, 11, 5-22.

Bennell, P., \& Akyeampong, K. (2007). Teacher motivation in Sub-Saharan Africa and South Asia. London: Department for International Development.

Best, J. W., \& Khan, J. V. (2006). Research in education (10 $10^{\text {th }}$ ed.). Boston: Allyn and Bacon.

Boimanda, A.Y. (2004). The decline in the professional code of conduct among the teachers in Tanzanian public schools: Causes and implications. Unpublished M.A Dissertation, University of Dar es Salaam.

Braun, V., \& Clarke, V. (2006). Using thematic analysis in psychology. Qualitative Research in Psychology, 3, 77-101. https://doi.org/10.1191/1478088706qp063oa

Bray, M. (2003). Adverse effects of private supplementary tutoring: Dimensions, implications and government response. Paris: IIEP- UNESCO.

Campbell, E. (2003). The ethical teacher. Philadelphia: Open University Press.

Cohen, L., Manion, L., \& Marrison, K. (2000). Research methods in Education (5 $5^{\text {th }}$ ed.). London: Routledge Falmer. https://doi.org/10.4324/9780203224342

Cohen, L., Manion, L., \& Morrison, K. (2007). Research methods in education (6 ${ }^{\text {th }}$ ed.). London: Routledge Falmer.

Creswell, J. W. (2009). Research design: Qualitative, quantitative, and mixed methods approaches ( $3^{\text {rd }}$ ed.). Los Angeles: SAGE Publications.

Edmund, J. (2011, June 07). Mwalimu jela miaka sita kwa kujaribu kubaka mwanafunzi

Finlayson, M. (2009). The impacts of teacher Absenteeism on student performance: The case of the cobb country school district. Practicum paper, Kemnnesaw State University.

Fussy, D. (2012). The effectiveness of school heads in institutionalising teacher ethics in Tanzania. Unpublished M.A Dissertation. University of Dar es Salaam. Dar es Salaam.

Jerome, G. (2014). The effects of teacher professional malpractices on the teaching and learning process in Tanzanian secondary schools. Unpublished M.A Dissertation Teofilo Kisanji University. Mbeya.

Johnson, R. B., \& Turner, L. A. (2003). Data collection strategies in mixed methods research. In A. Tashakkori, and C.Teddlie (Eds.), Handbook of mixed methods in social and behavioural research (pp. 297-319). Thousand Oaks, CA: Sage.

Kothari, R. C. (2004). Research methodology: Methods and technique. New Delhi: Wiley Eastern Limited.

Kuleana (1999). The state of education in Tanzania: Crisis and opportunities. Dar es Salaam: Kuleana Centre for Children.

Leach, F., Machakanja, P., \& Mandoga, J. (2000). Preliminary investigations of the abuse of girls in Zimbabwe Junior Secondary Schools. London: DFID.

Lumadi, M. W. (2008). Teachers' exodus in South African schools: A smoke with burning fire. Contemporary issues in education research Third Quarter, 1(3). 
Mfaume, H. (2012). The role and Contribution of the Teachers' Service Department in the promotion of teacher ethics in Tanzania public secondary schools. Unpublished M.A Dissertation. University of Dar es Salaam. Dar es Salaam.

Mkumbo, K. (2012). Teachers' Commitment to and Experiences of the Teaching Profession in Tanzania: Findings of Focus Group Research. International Education Studies, 5(3), 222- 227. https://doi.org/10.5539/ies.v5n3p222

MoEC [Ministry of Education and Culture] (1995). Education and Training Policy. Dar es Salaam: MoEC. MoEC (2000). Teacher education master plan 2000-2005. Dar es Salaam: MoEC.

Mussa, H. (2011, June 18). Mwalimu abaka mtoto wa chekechea[A teacher rapes a nursery school girl]. Nipashe newspaper, 1-2.

Oziambo, B (2013). The nature of teacher professional misconduct in Tanzanian public primary schools: The case of sumbawanga municipal and rural districts. Journal of Education, 5(1), 81-93.

Oziambo, B. (2010). The contribution of head teachers in curbing teacher misconducts in public primary schools in Tanzania. Unpublished M.A Dissertation. University of Dar es Salaam, Dar es Salaam.

Patton, M. (2002). Qualitative evaluation and research methods. Thousand Oaks, CA: Sage Publications.

Pehlivan, I. (1998). Management of professional and organizational ethics. Ankara: Pegem Publishing.

Public Service Commission (2010). Teachers' service scheme. Dar es Salaam: Government Printers.

Sambo, W. A. L. (2001). The role of private tuition in secondary education in Tanzania. Papers in Education and Development, 21, 96-110.

Sumra, S. (2005). The living and working conditions of teachers in Tanzania. A research report. Dar es Salaam: Hakielimu \& Tanzania Teachers' Union.

Tellis, W. (1997). Application of case study methodology: The qualitative report, 3 (3). Retrieved July 19, 2015, from http://www.nova.edu/ssss/QR/QR3-3/tellis2.html

Towse, P., Kent, D., Osaki, F., \& Kirua, N. (2002). Non-graduate teacher recruitment and retention: Some factors affecting teacher effectiveness in Tanzania. Teaching and Teacher Education, 18(1), 637-652. https://doi.org/10.1016/S0742-051X(02)00024-0

TSD [Teacher Service Department] (2011). Teachers penalized for various disciplinary offences between 2008 and 2011 in the country. Dar es Salaam: Teacher Service Department.

UNESCO (2005). Education For All global monitoring report. Paris: UNESCO.

URT (2002). Public Service Act, 2002 and Regulations 2003. Dar es Salaam: Government Printers.

van Nuland, S. (2009). Teacher codes: Learning from experiences. Paris: UNESCO.

van Nuland, S., \& Khandelwal, B. P. (2006). Ethics in education: The role of teacher codes. Paris: UNESCO.

Yin, R. K. (2011). Qualitative research from start to finish. New York: The Guilford Press.

\section{Copyrights}

Copyright for this article is retained by the author(s), with first publication rights granted to the journal.

This is an open-access article distributed under the terms and conditions of the Creative Commons Attribution license which permits unrestricted use, distribution, and reproduction in any medium, provided the original work is properly cited. 